\title{
膀脂結石に対する穿孔発破の開発と応用
}

\author{
京都府立医科大学泌尿器科学教室（主任：渡辺 泱教授）
}

内田睦

\section{CONFINED BLASTING IN MICROEXPLOSION CYSTOLITHOTRIPSY}

\author{
Mutsumi Uchida \\ Department of Urology, Kyoto Prefectural University of Medicine \\ (Director: Prof. Hiroki Watanabe)
}

This paper is the 12 th report in a series of studies on the application of microexplosion to medicine and biology.

Microexplosion lithotripsy is a newly developed technique in our clinic to crush urinary stones with small quantities of explosives. A systematic research project has been performed since the first report of microexplosion lithotripsy in 1977. As a result, microexplosion was successfully applied to the destruction of bladder stones in 130 cases from 1981 to 1988.

In blasting to crush rocks in industrial works, two kinds of blasting are available: external charge blasting and confined blasting. The detonation power of the latter is 10 to 50 times larger than that of the former.

A detruction test using several kinds of spherical form model calculus and lead azide explosive was performed. The formula to calculate the suitable explosive dose was determined experimentally as shown below.

$$
\begin{array}{lll} 
& \text { L: } & \text { Dose }(\mathrm{mg}) \\
\mathrm{L}=\mathrm{CD}^{2} & \text { C: } & \text { Coefficient of blasting } \\
& \text { D: } & \text { Stone diameter }(\mathrm{cm})
\end{array}
$$

Thus the theory in general industrial blasting with massive explosives was proved to be effective also in microexplosion with small explosives.

An original electric drill system was developed to make a hole in stones for confined blasting. 60 cases, including 2 cases of giant bladder stones over $100 \mathrm{~g}$ in weight, were successfully treated by confined blasting using this system without any complication.

We consider that any bladder stones, however big or however many, can be treated by microexplosion lithotripsy with confined blasting.

要旨：本論文は微小発破の生体応用に関する研究の第12報に相当する.

微小発破による膀胱結石破砕は, 発破法の上からも, また発破理論上からも一般岩石発破の小割発破 に相当する. 小割発破には, 張り付け発破と穿孔発破とがあるが, 穿孔発破のほらが張り付け発破より も効率良く結石を破碎することができる.

私たちは, 膀胱結石に対する穿孔発破のための電気ドリル式膀胱結石穿孔装置を開発し，現在まで60 症例の穿孔発破による膀脂結石破砕に成功した。

本報では，この膀胱結石に対する穿孔発破の基礎的理論と機器の開発ならびにその臨床応用について 述ベた。

\section{緒 言}

本論文は, 微小発破の生体応用に関する研究の第 12 報に相当する.
微小発破の生体応用に関する研究は，1975年よりま ず膀胱結石破砝の研究から始められ, その基礎研究と して, 実験用爆薬の開発 ${ }^{11}$, 尿路結石の物理的諸性質の 
検討233)ならびに実験用モデル結石の開発4)，発破の副

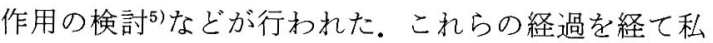
たちは, 1981年 9 月に初めて膀胒結石破砕の実用化に 成功し ${ }^{6)} ， 1988$ 年 8 月までに 130 症例全例に打いて，そ の破砕に成功を抢さめている。

当初私たちは，直径 $3 \mathrm{~cm}$ 程度の膀胱結石破砕をめさ し, 結石の表面に爆薬室を密着させて発破を行う張り 付け発破のみを施行してきたが，大きな膀胱結石を破 砕するには, 張り付け発破では効率が悪く, 張り付け 発破よりもはるかに効率の良い，結石にあらかじめ孔 をあけその孔の中に爆薬室を装填して発破する穿孔発 破の実用化が強く要請された。

本論文では，この穿孔発破の開発と応用について報 告する。

\section{電気ドリル式膀胱結石穿孔装置の開発}

私たちは，膀胱結石を穿孔するための装置として電 気ドリル式膀胱結石穿孔装置を開発した。この装置は, 穿孔用内視鏡，結石穿孔用ドリルならびにコントロー ルボックスとからなる(図 1)。穿孔用内視鏡は，外管 の径が Fr. 24でその中に光学管, 光学視管, 結石穿孔

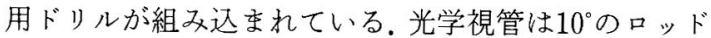
レンズを使用し，接眼部は本体より $60^{\circ}$ の角度で屈曲さ せた，一方結石穿孔用ドリルは，直径 $3.5 \mathrm{~mm}$ ，長さ 40 $\mathrm{cm}$ の回転軸からなり，ドリルの冈先としては通常の 歯科用サージカルバーを利用して 4 種作製した（図 2 ). 結石穿孔用ドリルの回転は, 膀胱外のコントロー ルボックスにより毎分500〜18,000回転の間で連続可 変され, 内視鏡を通して直線的に伝達されるようにし た。

\section{実験方法}

1) 電気ドリル式膀脱結石穿孔装置の刃先の選択 電気ドリル式膀胱結石穿孔装置の刃先として作製し た 4 種を使用して, モデル結石に直径 $3.2 \mathrm{~mm}$, 深さ 1 $\mathrm{cm}$ の穿孔をするために要する時間を比較した。

2) 張り付け発破と穿孔発破によるモデル結石破砕 状況の比較

当教室が開発した $2 \mathrm{mg}, 5 \mathrm{mg}, 10 \mathrm{mg}$ の実験用アジ化 鉛爆薬と，当教室が開発した各種大きさの圧縮強度 65 $\mathrm{kg} / \mathrm{cm}^{2}$ 前後の球状モデル結石を使用して, 張り付け発 破と穿孔発破の結石破砕状況を比較した。この際モデ ル結石は, 直径 $0.5 \mathrm{~cm}, 1.0 \mathrm{~cm}, 2.0 \mathrm{~cm}, 2.5 \mathrm{~cm}, 3.0$ $\mathrm{cm}, 4.0 \mathrm{~cm}, 5.0 \mathrm{~cm}, 5.5 \mathrm{~cm}, 6.0 \mathrm{~cm}$ の大きさのもの を作製した。 やや大きめの $3.2 \mathrm{~mm}$ とし, その穿孔の深さはモデル結
図 1 電気ドリル式膀胼結石穿孔装置 $\mathrm{A}$ ：穿孔用内視鏡， B：結石穿孔用ドリル，C：コン トロールボックス

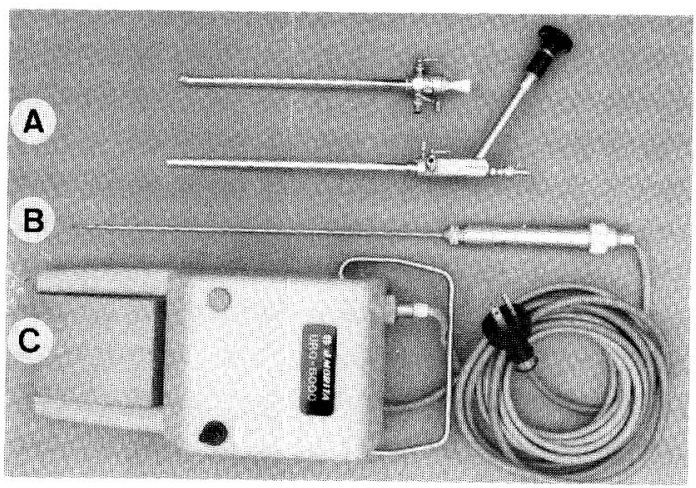

図 2 結石穿孔用ドリルの刃先

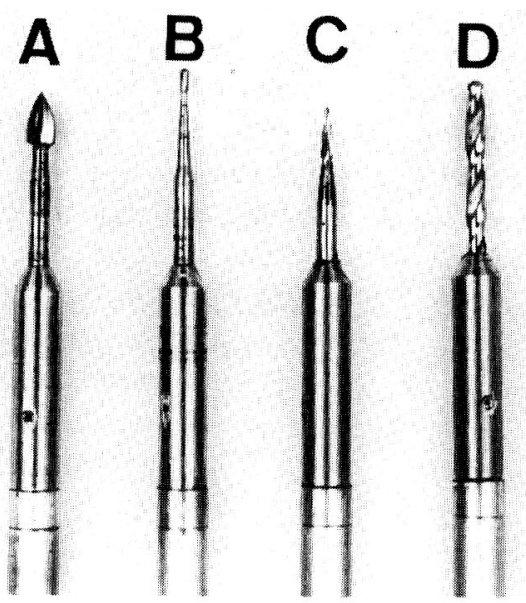

石の中心までとした.

3）穿孔の深さが結石破砝状況に及汸す影響

直径 $2 \mathrm{~cm}$ の球状モデル結石と $2 \mathrm{mg}$ アジ化鉛爆薬を 使用して，穿孔が結石中心まで及ばなかった場合，穿 孔が結石中心まで拉よび穿孔が結石中心を通過してし まった場合における結石の破砕状況を検討した。この 際穿孔の深さは, $0.5 \mathrm{~cm}$ すなわち中心に達せず, $1.0 \mathrm{~cm}$ すなわち中心すで， $1.5 \mathrm{~cm}$ すなわち中心を通過の 3 条 件とした。

4）穿孔個数が結石破砕状況に及ぼす影響

直径 $2 \mathrm{~cm}$ の球状モデル結石に 1 か所, 2 か所, 3 か 所の 3 種の穿孔を施行し, $2 \mathrm{mg}$ のアジ化鉛爆薬をその 中のひとつに装媜して発破し, 結石破砕状況を比較し た。この際穿孔の深さは $0.5 \mathrm{~cm}$ とした. 


\section{実験結果}

1）電気ドリル式膀胱結石穿孔装置の刃先

作製された 4 種のドリルの刃先を使用して穿孔に要 する時間を測定した結果 (表 1 ), 図 $2 \mathrm{~A}$ がわずか45秒 で穿孔発破可能な孔を作製することができ，電気ドリ ル式膀脱結石穿孔装置の刃先として最も適していた。

2) 張り付け発破と穿孔発破によるモデル結石破砕 状況の比較

張り付け発破と穿孔発破のモデル結石破砕状況の結 果は，表 2 のごとくであった。ここで○印はモデル結 石が粉々に粉破された状態(完全粉砕)，○印はモデル 結石の半分以上が粉砕された状態(粉砕)， $\triangle$ 印はモデ ル結石の半分以下だけが粉碎された状態（部分粉 砕)，×印はまったく破砕されない状態 (不変)を示し ている。すなわち一般の発破に扮ける用語を借りると, ○印は過装薬，○印は適正装薬， $\triangle$ 印拈よび×印は弱 装薬の状態を示している訳である。

この表から, 同一薬量でモデル結石破砕状況を比較 すると, 張り付け破砕よりも穿孔発破のほうが，上り 大きなモデル結石を破砕することができ，効率の良い ことがわかった。

またこのモデル結石破砕状況の結果を，印，○印， ○印の各破砕状況に分けて，それぞれ横軸にモデル結 石の直径 $(\mathrm{cm})$, 縦軸に薬量 $(\mathrm{mg})$ をとった両対数グ ラフに示すと, 図 3 のように張り付け発破, 穿孔発破 ともその破砕状況はほぼ直線的になり，比例関係にあ ることがわかった。しかもこの時の勾配はお打よそ 2 となり, 薬量を $\mathrm{L}(\mathrm{mg})$, 結石の直径を $\mathrm{D}(\mathrm{cm})$ とす ると,

$\mathrm{L}=\mathrm{CD}^{2}$

の関係式が成立した. この際の Cは，Dが 1 のときの 縦軸 $\mathrm{L}$ の値となり，各破砕状況に打いて一定の值とな る.

\section{3）穿孔の深さが結石破研状況に及ぼす影響}

穿孔の深さによる結石破砕状況は, 穿孔が中心に達 しない場合は, 結石が部分的に破砕され弱装薬の状態 で，穿孔が中心の場合，結石は破砕され適正装薬の状 態であった．また，穿孔が中心を通過した場合は，結 石が 2 分割されただけで，非効率的であった。

4）穿孔個数が結石破砕状況に及ぼす影響

穿孔個数による結石破砕状況は，穿孔が 1 か所の場 合は爆薬を装塤した結石の対側が破砕されずに残り， 穿孔が 2 か所の場合は結石は粉砕された。また，穿孔 が 3 か所の場合は結石は穿孔した孔の方向に 3 分割さ
表 1 各種刃先の穿孔に要する時間

\begin{tabular}{c|c|c|c|c}
\hline 刃先 & $\mathrm{A}$ & $\mathrm{B}$ & $\mathrm{C}$ & $\mathrm{D}$ \\
\hline 時間 & 45 秒 & 195 秒 & 240 秒 & 135 秒 \\
\hline
\end{tabular}

表 2 張り付け発破と穿孔発破の結石破砕状況

\begin{tabular}{|c|c|c|c|c|c|c|c|}
\hline \multicolumn{2}{|c|}{ 薬量 (mg) } & \multicolumn{2}{|c|}{2} & \multicolumn{2}{|c|}{5} & \multicolumn{2}{|c|}{10} \\
\hline & 発破法 & 張付 & 穿孔 & 張付 & 穿孔 & 張付 & 穿孔 \\
\hline \multirow[b]{2}{*}{ 結 } & 0.5 & (a) & & & & & \\
\hline & 1.0 & 0 & (a) & () & & & \\
\hline \multirow{2}{*}{ 石 } & 2.0 & $\triangle$ & (C) & 0 & (C) & (C) & (2) \\
\hline & 2.5 & $\times$ & 0 & $\triangle$ & (a) & 0 & (2) \\
\hline \multirow[t]{2}{*}{ 直 } & 3.0 & & $\times$ & $\times$ & (2) & 0 & (a) \\
\hline & 4.0 & & & & $\triangle$ & $\triangle$ & (2) \\
\hline 径 & 5.0 & & & & $\times$ & $x$ & (O) \\
\hline \multirow[t]{2}{*}{$(\mathrm{cm})$} & 5.5 & & & & & & 0 \\
\hline & 6.0 & & & & & & $\triangle$ \\
\hline
\end{tabular}

( ) : 完全粉砕 $\bigcirc$ : 粉碎 $\triangle$ : 部分破砕 $\times$ : 不変

、: 施行せず

図 3 張り付け発破と穿孔発破の結石破碎状況
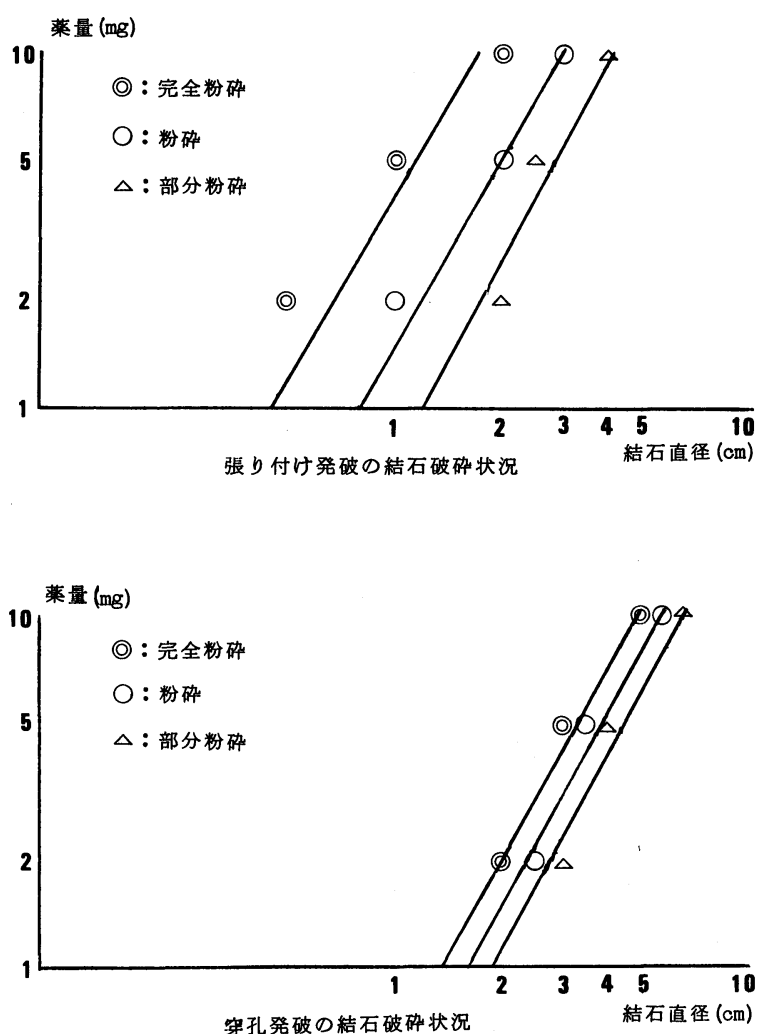
図 4 膀脱結石破碎状況

$\mathrm{A}$ ：膀胱結石穿孔中, $\mathrm{B}$ ：膀胼結石穿孔後, $\mathrm{C}$ ：膀胱結石穿孔発破直前, $\mathrm{D}$ ：膀胱結 石穿孔発破直後
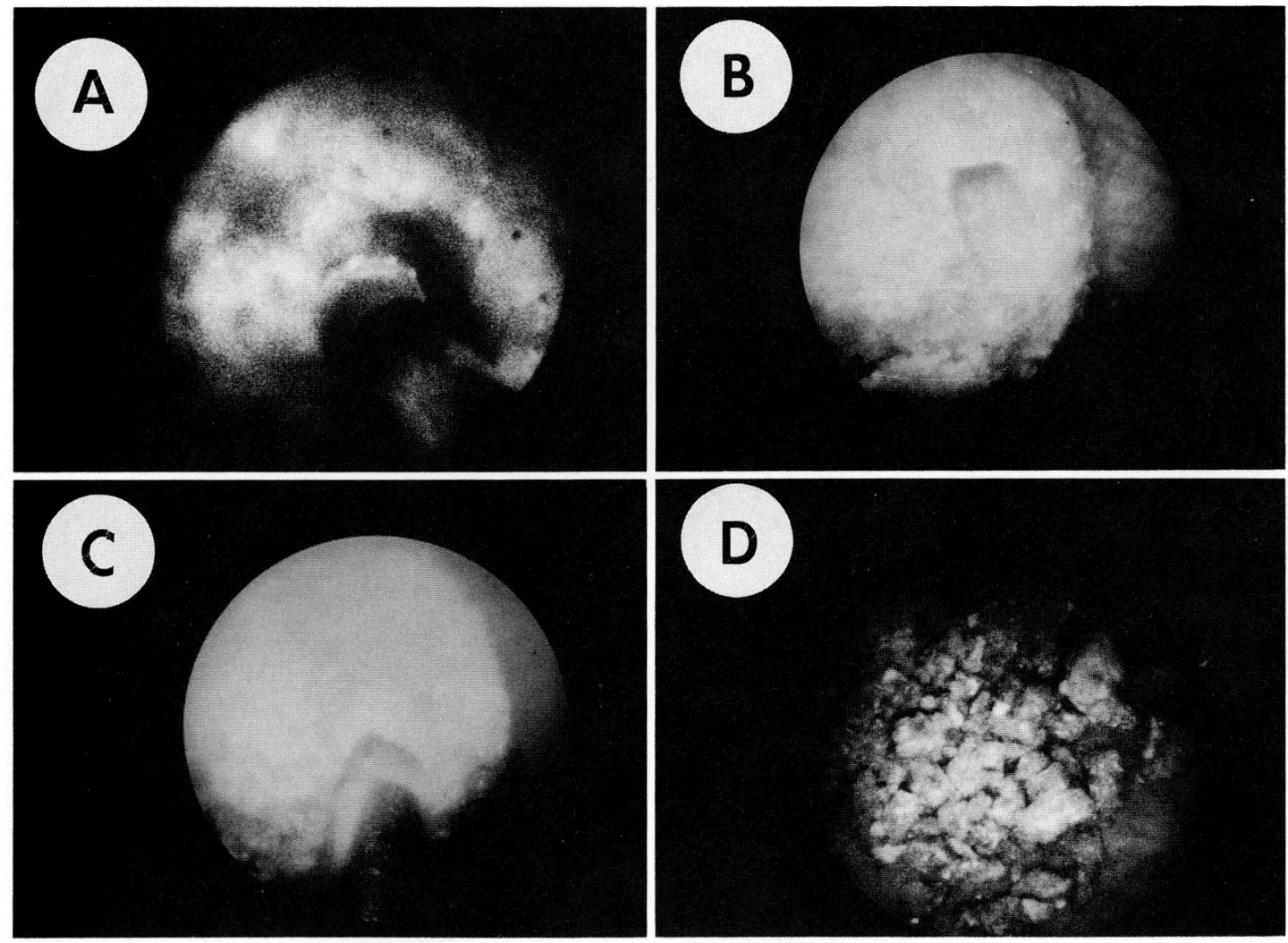

れた.これは, 穿孔が 1 か所の場合は穿孔の深さが 0.5 $\mathrm{cm}$ のため弱装薬の状態であったからで, 穿孔が 2 か 所の場合は結石が脆くなり穿孔が浅くとも爆薬の破砕 力が適正に反映したたためであった，穿孔が 3 か所の 場合は穿孔した孔のために衝撃波が減衰し，破砕力が 低下したためであった。

\section{穿孔発破の臨床応用}

\section{1) 対象}

私たちは，1983年 3 月より1988年 8 月までに，電気 ドリル式膀胱結石穿孔装置を使用して 60 症例に対し膀 胼結石穿孔発破を施行した。 60 症例のうち男性は47人, 女性は13人で, 男女比は $3.6: 1$ であった。年龄は20歳 から91歳に分布し，平均65.6歳であった。穿孔発破の みの症例は37例で, 穿孔発破と張り付無破を併用し た症例は23例であった。

\section{2) 手技}

手術は，まず穿孔用内視鏡にて膀胱結石を確認した
後, 結石穿孔用ドリルを膀胱結石にあて, ドリルの回 転を $5,000 \sim 7,000$ 回転にして, 直視下に膀胱結石に穿 孔した。この際膀胱結石をドリルで膀胱後壁に押しつ けながら軽く固定すれば,ドリルの回転数が高いので, たと直径 $1 \mathrm{~cm}$ の小さな膀胱結石でも結石は回転せ ず，容易に穿孔可能であった。

つぎに, 結石破挽用膀胱鏡を通して, カテーテル付 き爆薬室を結石の孔の中に装填して発破した（図 4). 結石を粉砕した後, エリック式吸引器にて破砕された 結石をすべて吸引摘出した。結石摘出後, 膀胱内にカ テーテルを留置し，翌日拔去した。

3) 臨床結果

60症例の膀朕結石患者に対して穿孔発破を施行した 結果，その全例に成功をおさめた，60症例全例におい て，電気ドリルによる穿孔はきわめて容易で，穿孔に 要した時間は 5 １0分であった. 結石の大きさは, $10 \times$ $10 \mathrm{~mm} \sim 115 \times 80 \mathrm{~mm}$ で，平均 $36 \times 26 \mathrm{~mm}$ であった。 
表 3 電気ドリル式膀胱結石穿孔装置による穿孔発破症例

\begin{tabular}{|c|c|c|c|}
\hline 法 & 症例数 & 結石の大きさ (平均) & 結石の重量 (平均) \\
\hline $\begin{array}{l}\text { 穿孔発 破 } \\
\text { 張り付発破十架孔発破 }\end{array}$ & $\begin{array}{l}37 \\
23\end{array}$ & $\begin{array}{l}10 \sim 50 \mathrm{~mm}(30) \\
27 \sim 115 \mathrm{~mm}(35)\end{array}$ & $\begin{array}{l}1 \sim 50 \mathrm{~g} \quad(12) \\
8 \sim 305 \mathrm{~g} \quad(51)\end{array}$ \\
\hline 計 & 60 & $10 \sim 115 \mathrm{~mm}$ & $1 \sim 305 \mathrm{~g} \quad(25)$ \\
\hline
\end{tabular}

図 5 症例の膀脂結石

$\mathrm{A}$ ：X 線単純写真, B：摘出結石

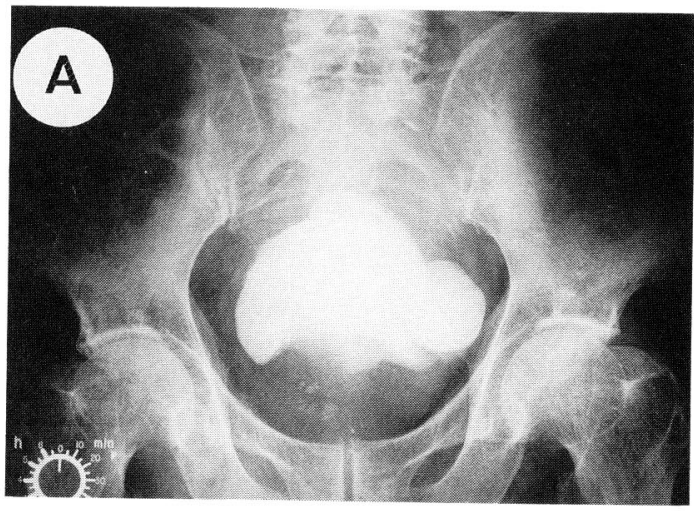

た摘出された結石重量は，1～305g で平均 $25 \mathrm{~g}$ であっ た(表 3 ).

また合併症としては，内視鏡操作による軽度血尿を 認めただけであった。

4) 症例

症例は尿道狭窄を有する91歳の男性で，X 線写真上 $115 \times 80 \mathrm{~mm}$ の膀脱結石を認めた。この症例の場合，尿 道狭窄のために経尿道的操作が困難で， ず超音波穿 刺術による経皮的膀腃瘦造設術を施行した。この後, 膀胼瘦から穿孔执よび張り付讨発破を計30回施行し, 完全に結石を摘出し得た(摘出総重量 $305 \mathrm{~g}$ )。この際順 行性尿道拡張術も施行し, 尿道狭窄をも治癒せしめた (図 5 ).

\section{考察}

微小発破による膀胱結石破砕術は，1981年 9 月より 1988年 8 月末での 7 年間に 130 症例施行し, その全例に 打いて成功をおさめている。当初私たちは, 直径 $3 \mathrm{~cm}$ 程度の膀胱結石破砕をめざし, 張り付け発破のみを施 行してきたが，私たちの外来を訪れる患者の中には， 直径 $5 \mathrm{~cm}$ を越える巨大な膀脱結石患者も少なくな かった。このよらな膀胱結石を破砕するために，一般 岩石発破では破砕効率の良いとされる穿孔発破の開発 が必要とされた。

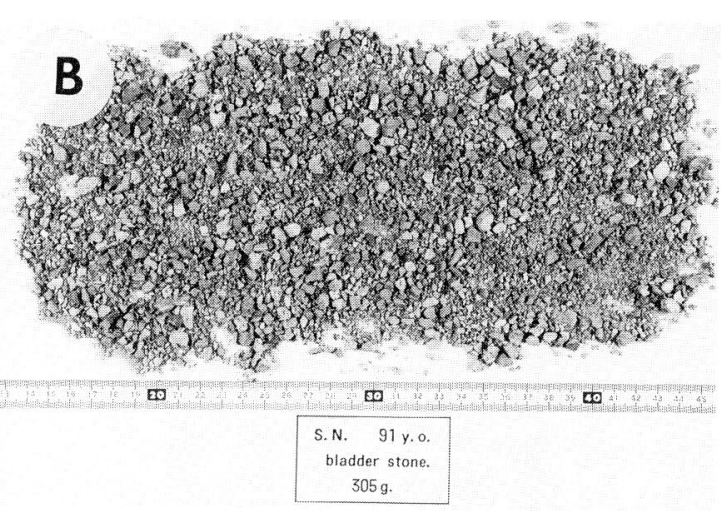

図 6 微小発破に打ける小割発破

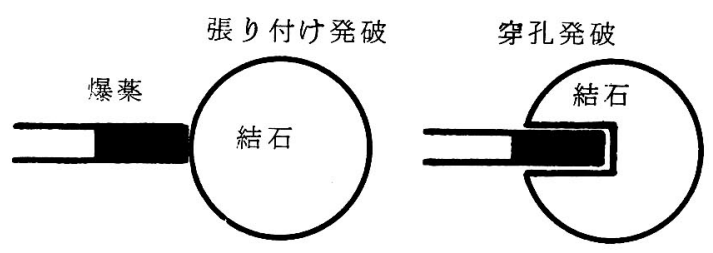

一般岩石発破に抮いては，大さな岩石を持ち運びで さるよらに小さくするために行ら発破を小割発破とい らが，私たちの微小発破による膀胼結石破砕は，発破 形成からはこの小割発破に相当する(図6)。小割発破 には大きく分けて，張り付け発破と穿孔発破の二つの 万法があり ${ }^{7)}$, この薬量計算式は経験的に L を薬量, D を岩石の短径，Cを発破係数とすると， $\mathrm{L}=\mathrm{CD}^{2}$ で示さ れる ${ }^{8)}$.この際の発破係数 C は, ある体積を破砕するの に要する薬量を決定する係数で, 爆薬の威力, 破砕す る岩石の強度，発破方法などによって異なる。すなわ ち，同じ体積のものを破砕するのに，この発破係数の 值が小さけ扎ば小さい汪ど，使用する爆薬量は少なく てすさことになる訳である。

私は，一般岩石発破とは比較にならないほど微量の 爆薬を使用する微小発破に扣いても，一般岩石の小割 
表 4 膀胱結石破砕至適爆薬量

\begin{tabular}{c|c|c|c|c|c|c|c}
\hline $\begin{array}{c}\text { 結石短径 } \\
(\mathrm{cm})\end{array}$ & 1.0 & 1.5 & 2.0 & 2.5 & 3.0 & 3.5 & 4.0 \\
\hline $\begin{array}{c}\text { 張り付け発破 } \\
(\mathrm{mg})\end{array}$ & 2 & 3 & 6 & - & - & - & - \\
\hline $\begin{array}{c}\text { 穿孔発破 } \\
(\mathrm{mg})\end{array}$ & - & 1 & 2 & 3 & 4 & 5 & 7 \\
\hline
\end{tabular}

発破の理論が適用するかどらかをモデル結石を使用し て検討した。その結果, 微小発破による膀胱結石破砕 は, 発破形式の点からも, また発破理論の点からも, 一般岩石発破の小割発破に相当していることが明らか となった。 また図 3 の適性装薬の状態である○印の直 線から発破係数を求め, 下記のような微小発破による 膀胱結石破砕の薬量計算式を決定した。

張り付け発破 $\mathrm{L}(\mathrm{mg})=1.5 \mathrm{D}^{2}(\mathrm{~cm})$

穿孔発破 $\mathrm{L}(\mathrm{mg})=0.45 \mathrm{D}^{2}(\mathrm{~cm})$

そしてこの薬量計算式から, 表 4 のごとく膀胱結石 破砕破砕至適爆薬量を算出した。すなわちこの表から， 結石の大きさがわかればすぐに膀胱結石破砕至適爆薬 量がわかることになる。私たちは現在一般臨床におい て, この至適爆薬量を役立てている。

以上述べた穿孔発破に拈ける実験結果は, 穿孔は 1 か所のみ，穿孔の深さは結石の中心までといら条件で 成立するものである。しかし実際の臨床においては, このように正確に結石に穿孔することは困難である. そこで，穿孔の深さが結石破砕状況に及ぼす影響，な らびに穿孔個数が結石破砕状況に及ぼす影響について も検討した。この結果臨床的には, 穿孔が結石の中心 に達しない場合は, 適正装薬以上の爆薬量が必要であ り，穿孔が結石の中心を通過した場合は，2 分割され るだけで破砕効率が悪くなることが証明された。また 穿孔の深さが浅い場合, 爆薬量を增やさずとも穿孔の 数を 2 か所にすれば, 結石は十分破砕されることが証 明された。したがって, 穿孔の深さが結石中心に達し ていない場合や, 複数の穿孔を行った場合は, 膀胱結 石破砕至適爆薬量を調節することが必要である。

張り付け発破に比較して, 穿孔発破はょり少ない薬 量で大きな結石を破砕することができ，有意義である ことがモデル結石破砕実験からも立証されたが, 実際 結石に穿孔することのできる適当な装置はなかった。 わずかに超音波砕石器9), レーザー光線 ${ }^{10)}$ が研究され ていたが, 超音波砕石器は結石破砝効果が悪く穿孔す るのに時間を要し, レーザー光線は光導系や破砕効果
に問題があり，両者とも穿孔するための装置としては 不適当であると思われた。 そこで私たちはより迅速に， 誰でも簡単に膀胱結石に穿孔することができ，しかも 安価なドリルによる結石穿孔装置を開発した。この装 置を使用すれば，いかなる膀胱結石でもわずかに 5 〜10分で穿孔発破可能な孔を作製することができ，き わめて有用であった。したがって穿孔発破の開発当初 は, 結石の短径が $3 \mathrm{~cm}$ を越えるような巨大膀胱結石破 砕を目的としていたが, 後には短径 $3 \mathrm{~cm}$ 以下の膀胱結 石でも穿孔可能であれば，破砕効率が良く爆薬量を少 なくできる穿孔発破を施行するようになった。事実私 たちの症例のなかには, わずか直径 $1 \mathrm{~cm}$ の膀脱結石穿 孔発破に成功した症例も含まれている.

膀胱結石症に対する非観血的手術療法は，1626年 Sanctoriusにより砕石器がはじめて考案されたが, 1824年 Civialeにより改良が加兄られ, 比較的安全に 施行されるようになった。後種々の砕石器が工夫さ れたが, 1878年 Bigelowによりはじめて現代的な破石 器が考案された。しかしこれらの破石器は，いずれも 盲目的操作を必要とした。 1907年 Walker ${ }^{11}$ により，か なり強度の大きいレンズ付き破石器が考案されたが, これとても $2.5 \mathrm{~cm}$ 以下の硬くない結石のみにしか使 用できないものであった。さらに Hendricksonや Mauermayer $ら^{12)}$ は, 現代的な膀胼鏡による砕石器を 開発した。しかし, 非観血的手術療法には, 膀羘出血, 膀胼破裂, 尿道損傷などの合併症が多く認められ, 結 石を簡単に破砕することのできる装置の開発が望まれ ていた。

このよらななかで, 1950年 Yutkin が電気水圧衝撃 波の破壊作用を発見し，1959年 Goldberg が電気水圧 衝撃波砕石器を使用して, 膀胱結石破碎の臨床応用に 成功した。 以来この装置は世界中に広まった。しかし 諸家の報告 ${ }^{13) 14}$ によると，その成功率はいずれも $90 \%$ 前後で, しかもこれまで破砕摘出された最大の結石重 量は130g であった。合併症としては膀胼破裂が多く， 1981年 Bülow ら ${ }^{15)}$ の報告では，304例中 6 例 ( $\left.2 \%\right)$ に これが認められた。

また，超音波による結石破砕の研究も時をほぼ同じ くして1950年代よりはじまり ${ }^{16)}, 1972$ 年 Terhorst ら ${ }^{17)}$ により超音波砕石器が作製され, 膀胱結石破砝に応用 された。しかし，この超音波砕石器による膀胱結石破 砕は, Marberger ${ }^{18)}$ も指摘しているように安全ではあ るが，破砕効率の低さから大きな結石破碎には適して いなかった。合併症としては, 1983年 Hautmann ら ${ }^{19)}$ 
の報告では，操作中の膀胱破裂が412例中 5 例(1.3\%) に認められた。

これら二つの結石破砕装置が開発され，非観血的手 術の応用範囲はかなり拡大されたが，砕石できる結石 の大ささに限界があり，膀腅結石に関するかぎり観血 的手術に一歩を譲っていたのがこれまでの現状であ る. 事実, 1978年 Becker ら ${ }^{20)}, 1981$ 年 Kossow ${ }^{21)}, 1983$ 年 Laubscher ${ }^{22)}$ が報告しているように，現在でも $100 \mathrm{~g}$ 以上の膀胱結石にはいずれも観血的手術が施行されて いる.

このように，これまでの膀胱結石に対する非観血的 手術療法には限界が認められ, すべての症例に適応で きる完全な治療法として確立されたものは何ひとつと してなかった。しかし，私たちの開発した穿孔発破に よる膀胱結石破碎術はこの限界を打破するものであっ た。実際に，私たちの経験した60例の穿孔発破症例の 中には， $305 \mathrm{~g}$ をはじめとして $100 \mathrm{~g}$ 以上の膀胱結石が 2 例含まれているが，いずれも合併症なしに非観血的 に破砕摘出されている。私たちはこの穿孔発破の開発 により，膀胱結石に対する観血的手術療法はもはや過 去のものになったと考えている.

さて膀胼結石は，発展途上国に扣いて特に発生率が 高いことが知られており, 東南アジア諸国に招いては, 泌尿器科入院患者の過半数が膀胼結石によって占めら れていると聞く. 当教室においては, 将来的にこのよ らな地域を対象に, 微小発破による膀胱結石破砕を積 極的に普及させていく方針であり，すでにその具体的 計画に着手している，一方中国においては，私たちの アイデアに基づいて独自に微小発破を開発した西安市 を中心とするグループが，同じく多数例の膀胱結石治 療に成功している23).

このように微小発破の技術は，ひとり日本国内に打 ける実用化にとどまらず，すでに国際的レベルにおい てその普及が期待されている。私たちもさらに一層の 努力をかさね, この純国産の新技術の発展につくした いと考えている。

\section{結 語}

穿孔発破による膀腑結石破砕の開発と電気ドリル式 膀胱結石破孔装置の開発ならびにその臨床応用につい て述べた。

この微小発破による膀胱結石破砕の方法は，いかな る膀胱結石でも合併症なしに破砕摘出することがで き, 従来の観血的手術に比べて安全で, 侵襲が小さく, 再発する患者に何度でも施行できるなど，優れている
点が多い.したがって私たちは, 近い将来この方法が, これまでの観血的手術にとってかわり，膀胼結石治療 の主流となることを確信している。

稿を終わるに臨み,この優れた方法を着想され，また本研 究のご指導と本稿のご校閲をいただいた恩師渡辺泱教授に 心からの感謝の意を表する。 また本研究の遂行にあたって, 共同研究者としてご協力いただいた下記の方々に, あつく 御礼申し上げる.

\section{共同研究者}

京都府立医科大学泌尿器科学教室 渡辺康介, 金子 宏, 近藤和秀, 中河裕治. 通商産業省工業技術院化学技術研究所 生沼仙三, 椎野和夫, 田中一三. 細谷火工株式会社 上谷 長俊, 村上豊司, 大森正義. 株式会社モリ夕製作所 上田晴 彦, 團 和夫.

なお本研究は, 文部省科学研究費 ( 8 件), および科学技 術庁特別研究促進調整費により行われた。

本論文の要旨は, 第22回日本 $\mathrm{ME}$ 学会大会（1983年 4 月 13日, 東京都) 招上び第33回日本泌尿器科学会中部総会 （1983年11月12日，浜松市）において報告した。

\section{文献}

1）渡辺 決, 生沼仙三：徽小発破の生体応用に関す る研究. 第 1 報。実験用爆薬の試作。日泌尿会誌, 68, 243-248, 1977.

2）村田庄平, 渡辺 浃, 高橋 徹, 渡辺康介, 古江治 美, 生沼仙三: 微小発破の生体応用に関する研究. 第 2 報。尿路結石の組成と強度。日泌尿会誌，68, 249-257, 1977.

3）金子宏, 渡辺 決, 高橋徹, 渡辺康介, 秋山喜 久夫, 近藤和秀, 古江治美, 生沼仙三：微小発破の 生体応用に関する研究. 第 4 報。湿状態および乾燥 状態に抢ける尿路結石の強度. 日泌尿会誌, 70, 61-66, 1979.

4）内田 睦, 近藤和秀, 中河裕治, 藤戸浩二, 今出陽 一朗, 河内明宏, 渡辺 泱：墱小破の生体応用に 関する研究. 第11報. 実験的モデル結石の開発. 日 泌尿会誌，76，1309-1313， 1985.

5）渡辺康介：微小発破の生体応用に関する研究. 第 7 報。微小発破に上る膀胖の障害度. 日泌尿会誌, 74, 299-310, 1983.

6) Watanabe, H., Watanabe, K., Shiino, K. and Oinuma, S.: Micro-explosion cystolithotripsy. J. Urol., 129, 23-28, 1983.

7）通商産業省立地公害局編：火薬類保安教本シリー ズ3, 発破 (各論). p. 101-105, 全国火薬類保安 協会, 東京, 1979 .

8）木村 貞, 鈴木善孝：火薬技術者必携. 第 3 版, p. 279, 産業図書, 東京, 1976.

9) Mulvaney, W.P.: Attempted disintegration of calculi ultrasonic vibrations. J. Urol., 70, 707, 
1953.

10) Watoson, G.M.: Lasers in Urologic surgery, chapter 10, laser fragmentation of urinary calculi. 120-137, Year Book Medical Publishers, Chicago, 1985.

11) Walker, G.: A new combined lithotrite with cystoscope. Ann. Sur., 46, 452-458, 1907.

12) Mauermayer, W.: Transurethral Surgery, Chapter I, Litholapaxy, 359-367, SpringerVerlag, Berlin, Heidelberg and New York, 1983.

13) Raney, A.M.: Electrohydraulic cystolithotripsy. Urology, 7, 379-381, 1976.

14) Comisarow, R.H. and Barkin, M.: Electrohydraulic cystolitholapaxy. Can. J. Surg., 22, 525-526, 1979.

15) Bülow, H. and Frohmüller, H.G.W.: Electrohydraulic lithotripsy with aspiration of the fragments under vision- 304 consecutive cases. J. Urol., 126, 454-456, 1981.

16) Mulvaney, W.P.: Attempted disintegration of calculi by ultrasonic vibrations. J. Urol., 70 , 704-707, 1953.

17) Terhorst, B., Lutzeyer, W., Cichos, M. and Pohlman, R. : Die Zerstörung von Harnsteinen durch Ultraschall, II. Ultraschall-Lithotripsie von Blasensteinen. Urol. Int., 27, 458-469, 1972.

18) Marberger, M.: Ultrasound in Urology, Chapter 19, Ultrasonic Destruction of Bladder Stones, 371-376, Williams \& Wilkins Company, Baltimore, 1979.

19) Hautmann, R., Terhorst, B., Rathert, P., Gminder, F. and Lutzeyer, W.: Urinary Stone, 22, Ultrasonic Litholapaxy of Bladder Stones 10 years of Experience with More Than 400 Cases, p. 120-124, Churchill Livingstone, London and New York, 1983.

20) Becker, R.M., Tolia, B.M. and Newman, H.R.: Giant vesical calculus. J.A.M.A., 239, 22722273, 1978.

21) Kossow, CDR. A.S.: Giant bladder calculus, case report. Military Medicine, 146, 783-784, 1981.

22) Laubscher, H.H.: Giant vesical calculus, a case report. S. Afr. Med. J., 63, 209-210, 1983.

23) Xui, M., Chang, J., Xui, Z., Cheng, W., Bao, Z., Shi, $Z$. and Wang, J. : Microexplosion of bladder stone. Chinese Med. J., 61, 341, 1981.

（1988年12月15日受理） 